\title{
Institutions and coalitions in policy processes: a cross-sectoral comparison
}

\author{
MANUEL FISCHER \\ Swiss Federal Institute for Aquatic Research and Technology Eawag and University of Berne, Switzerland \\ E-mail: manuel.fischer@eawag.ch
}

\begin{abstract}
Actors with joint beliefs in a decision-making process form coalitions in order to translate their goals into policy. Yet, coalitions are not formed in an institutional void, but rather institutions confer opportunities and constraints to actors. This paper studies the institutional conditions under which either coalition structures with a dominant coalition or with competing coalitions emerge. It takes into account three conditions, i.e. the degree of federalism of a project, its degree of Europeanisation and the openness of the pre-parliamentary phase of the decision-making process. The cross-sectoral comparison includes the 11 most important decision-making processes in Switzerland between 2001 and 2006 with a fuzzy-set Qualitative Comparative Analysis. Results suggest that Europeanisation or an open pre-parliamentary phase lead to a dominant coalition, whereas only a specific combination of all three conditions is able to explain a structure with competing coalitions.
\end{abstract}

Key words: coalitions, institutions, policy process, QCA, SNA, Switzerland

\section{INTRODUCTION}

In modern political systems, no collective actor is able to decisively influence decision-making on its own. Owing to the increasing complexity of political problems and the need for organisational resources, actors with similar preferences form coalitions. Coalition formation among political parties is a well-known feature of legislative politics (e.g. Laver and Schofield 1990; Mueller and Strom 2000). However, looking beyond the parliamentary arena, several theories of the policy process, such as the Advocacy Coalition Framework (ACF, Sabatier 1987), the Punctuated Equilibrium Theory (Baumgartner and Jones 1993) or the Policy Network Approach (e.g. Adam and Kriesi 2007), focus on coalitions involving political parties, interest groups, administrative agencies or subnational actors. Scholarly interest for coalitions in policy processes rests upon the 
premise that the coalition structure has consequences on the outcome of a policy process (e.g. Knoke et al. 1996; Adam and Kriesi 2007).

Yet, coalitions do not form in an institutional void. Just as institutional rules influence the formation of coalition governments (e.g. Mueller and Strom 2000), the emergence of coalitions in the policy process depends on the institutional contexts that confer opportunities and constraints to actors (Kübler 2001). An example for institutional constraints are veto points (Immergut 1990) that require the formation of broad coalitions (Sabatier and Weible 2007, 200). Institutional opportunities are, for example, given by working groups that are accessible to non-state actors and enable actors' coordination (Leifeld and Schneider 2012).

The role of the institutional context for coalition formation is, however, largely neglected in the literature. While the ACF (Sabatier 1987) suggests that the similar preferences of actors are the main element explaining coalition formation, the interplay between beliefs, institutions and coalition formation is not well established (Weible and Sabatier 2005; Sabatier and Weible 2007; Weible et al. 2011). Institutional explanations have only recently been integrated into research on the Policy Network Approach (e.g. Adam and Kriesi 2007; Leifeld and Schneider 2012). Studying the effects of institutions on coalition formation is important for at least two reasons. First, neglecting the institutional conditions under which coalitions form leads researchers to overemphasise the importance of preferences. Second, if institutions affect the coalition structure, then they are also important for understanding the prospects of policy change (Sabatier 1998; Sabatier and Weible 2007).

The aim of this paper is to study the influence of federalism, Europeanisation and venue openness on the coalition structure. Federalism and Europeanisation act as institutional constraints by defining the set of actors that need to be included in a dominant coalition. Open venues of the policy process, on the contrary, provide actors with opportunities for forming dominant coalitions. Federalism, Europeanisation and open venues are all expected to contribute to the emergence of dominant coalitions, while their absence is expected to lead to several competing coalitions.

I compare the 11 most important policy processes in Switzerland between 2001 and 2006. In the consensus democracy of Switzerland, the four biggest parties are included in government, but the Social Democrats and the Swiss People's Party, especially, oppose governmental projects on a regular basis (e.g. Kriesi and Trechsel 2008). Partly as a consequence thereof, the compositions of coalitions vary across projects, which makes Switzerland a good example to illustrate the effect of institutions on coalition formation. The 11 cases are compared by a Qualitative Comparative Analysis (QCA, Ragin 1987). Data were gathered through interviews with 
representatives of 251 collective political actors, as well as from extensive documentary sources on the 11 processes.

The remainder of this paper is structured as follows. The next section discusses theoretical elements on coalition formation. I then formulate expectations about the influence of institutional conditions on coalition structures. The third section presents data and methods, while the comparative analysis follows in the fourth section. The final section concludes.

\section{Coalition structures and institutional context}

\section{Coalition structures}

In modern political systems, no collective actor is able to decisively influence decision-making on its own. Whereas coalition formation is a well-known strategy used by political parties in parliament to pass legislation or form a government (e.g. Laver and Schofield 1990; Mueller and Strom 2000), there is broad evidence that actors also form coalitions in order to influence policy making beyond parliament (Sabatier 1987; Baumgartner and Jones 1993; Knoke et al. 1996; Adam and Kriesi 2007). Besides political parties, different types of actors, such as interest groups, state actors or subnational units, are part of coalitions. Coalitions are groups of actors with similar beliefs that engage in some degree of coordination in order to influence a policy project (Sabatier and Weible 2007). Forming coalitions allows them to coordinate their actions, join organisational and financial resources or demonstrate broad support for a project (Mahoney 2007). Most often such coalitions form only around a given policy project (Knoke 2011) and are informal (Heaney 2006). Besides benefits, being part of a coalition also implies costs for actors, as they have to invest in internal coordination and communication efforts and might have to give up parts of their own position (Schlager 1995; Knoke et al. 1996; Mahoney 2007; Henry 2011). There are usually two or three coalitions present in a given policy process (Sabatier 1987; Knoke et al. 1996; Sabatier and Weible 2007).

Besides their number, one needs to assess the power of coalitions. Indeed, the interest of assessing coalition structures is largely based on its crucial impact upon the outcomes of the process and the potential for policy change (e.g. Knoke et al. 1996; Adam and Kriesi 2007). If a broad majority of powerful actors form a single, dominant coalition, this coalition should be able to make its preferred policy outcome pass into legislation. ${ }^{1}$ Minority coalitions containing a small number of weak actors, if they exist, are

\footnotetext{
${ }^{1}$ Such a situation with a dominant coalition can indicate the existence of a policy monopoly (Baumgartner and Jones 1991).
} 
unable to decisively influence the outcome. However, note that a structure with a dominant coalition does not automatically lead to policy change, as this also depends on the preferences of the coalition. On the contrary, there may exist situations with several equally powerful coalitions (e.g. Weible 2005). In a situation of competing coalitions, policy change is unlikely, as coalitions can block each other or may have to negotiate lowest common denominator compromises.

To be sure, power is not the only characteristic that defines a coalition. Other important elements are the number of actors in a coalition, its cohesiveness and its internal agreement (i.e. Lubell et al. 2012, 353). However, as noted above, a large number of coalition members or strong internal coordination also imply costs. This complicates the link between these characteristics of coalitions and their ability to influence decisionmaking. I thus argue that power is an encompassing characteristic expressing a coalitions' ability to influence process outcomes, given the benefits and costs emerging from other coalition characteristics.

\section{Institutional conditions and coalition formation}

Coalition formation, maintenance and the strategies and resources available to them depend on the institutional context. Institutions refer to the formal and informal norms that both constrain and enable the behaviour of political actors (Ostrom 1990, 2005). Based on the literature on Political Opportunity Structures (e.g. Kriesi 1995), Kübler (2001) argues that coalitions adapt their strategies to the institutional context. Further, the "professional fora" facilitating cross-coalition learning (Sabatier 1987) are institutions offering opportunities for coalitions' learning processes. However, before being able to define strategies or learn, coalitions need to form. Coalition formation is also influenced by the institutional context, as institutions affect the collective action problem that actors face by influencing the costs and benefits of coalition formation (Schlager 1995).

While some institutions are constant within a country, others vary between policy subsystems. The influence of country-specific institutions on coalitions has been addressed elsewhere (e.g. Kübler 2001; Sabatier and Weible 2007; Nohrstedt 2011; Weible et al. 2011). In this paper, countryspecific institutions are constant, and I focus instead on subsystem-specific variation within one country. I consider three important institutions in Swiss politics (e.g. Kriesi and Trechsel 2008), i.e. federalism, Europeanisation and the venues of the preparatory phase of the policy process. ${ }^{2}$ While the first two

\footnotetext{
${ }^{2}$ Another institutional condition potentially influencing coalition structures is the referendum. However, this institution is very specific to the Swiss case. In addition, it depends,
} 
represent constraints for actors, the last condition acts as an opportunity for actors.

First, policy processes that touch upon the federalist organisation of competences bring strong constraints to actors for coalition-building. Federalism leads to power dispersion across the central state and the subnational units (e.g. Hooghe and Marks 2003). For example, in systems of cooperative federalism, decisions taken at the higher level are often implemented at the lower level, thereby conferring a de facto veto power to subnational units. While subnational governments are directly involved in decision-making at the higher level in Germany or the European Union (EU) (Scharpf 1988, 2006), Swiss cantons are granted an indirect veto power through the popular referendum (Fischer et al. 2010). ${ }^{3}$ The need to find solutions supported by both levels makes federal systems less prone to change (Scharpf 1988, 2006; Tsebelis 2002). The dispersion of power in federalist systems thus impacts upon the need for coalitions to include actors from both levels in order to increase their chances for success. This does not concern all policy processes in federalist systems, but rather only the ones that tackle the distribution of competences between the levels of the federalist state. If this is the case, cantons are directly concerned with decision-making at the national level and need to be included in a dominant coalition. Supported by a dominant coalition composed of both levels of the federalist state, a federalist project is unlikely to be hampered by other (e.g. the classical left-right) conflicts (Thomas 2001, 16f.; Linder 2005, 117). On the contrary, if all cantons or parts of them do not support a project, chances are high that it will fail sooner or later. Federalism thus acts as a constraint upon actors, i.e. it defines the set of actors that needs to be included in the dominant coalition. Federalism is therefore expected to contribute to the emergence of a dominant coalition. The absence of federalism favours competing coalitions.

Second, Europeanisation describes the phenomenon by which more and more domestic policy projects are influenced by the EU (e.g. Börzel and Risse 2000). Europeanisation affects not only substantive policies, but also domestic institutions and the constellation among domestic actors (Sciarini et al. 2004). In Europeanised projects, state executives try to achieve their foreign policy priorities in international negotiations. They play a "two-level game" (Putnam 1988), and their presence at the international negotiation table confers them power (Moravcsik 1993).

especially in its optional form, largely on actors' strategies and therefore cannot be considered as an external institutional factor affecting coalition formation.

${ }^{3}$ The double majority clause regarding the popular vote on constitutional amendments requires a majority of the people and a majority of cantons to accept a project. 
However, state actors also have to look for domestic support for an international treaty. While it is unclear whether Europeanisation increases or decreases domestic conflict (Fischer 2012, 82), state actors always face the risk that their international treaty fails in the domestic ratification phase. To reduce this risk and reach broad support for the treaty, they have to integrate the most important domestic non-state actors in a dominant coalition (Fischer and Sciarini 2013). The specific institutional design of Europeanised projects thus acts as a constraint for state actors. Europeanisation is expected to contribute to the emergence of a dominant coalition. On the contrary, if a project concerns domestic politics, this enables a structure with competing coalitions.

Third, political decision-making in modern democracies happens in different subsequent or parallel institutional venues, such as working groups or consultation procedures. Such institutional venues and actors' participation therein have been shown to foster cooperation among actors (Schneider et al. 2003; Leifeld and Schneider 2012). The venues vary in terms of their number and accessability for non-state actors (Sabatier and Weible 2007). The venues of the preparatory, pre-parliamentary phase are considered the most important in Swiss policy processes. Its working groups and consultation procedures offer access points for non-state actors that allow them to try to influence the project accordingly (e.g. Sciarini 2006). The accessibility of the preparatory phase positively influences actors' opportunities to form a dominant coalition. The possibility to participate in the open venues of the preparatory phase reduces the actors' costs of exchanging their views, establishing cooperation and negotiating a compromise solution. ${ }^{4}$ Open venues are thus expected to lead to the formation of a dominant coalition. In contrast, a closed preparatory phase contributes to a structure of competing coalitions.

Based on these arguments, I formulate the following set of hypotheses:

(H1): Federalism contributes to the emergence of a dominant coalition.

$(\mathrm{H} 2)$ : Europeanisation contributes to the emergence of a dominant coalition.

(H3): A policy process with open venues contributes to the emergence of a dominant coalition.

The absence of all three conditions should favour the emergence of competing coalitions.

\footnotetext{
${ }^{4}$ Note that a rival theoretical argument suggests that open institutional venues, rather than fostering cooperation and consensus seeking, provoke conflict (Leach et al. 2002).
} 


\section{Data and methods}

The analysis relies on a cross-sectoral comparison of the 11 most important policy processes in Switzerland between 2001 and 2006. ${ }^{5}$ Arguably, the most important processes may not be representative of the whole population of policy processes in Switzerland. Implications of case selection are discussed in the conclusions. The cases are the 11th pension reform, the programme of budget relief 2003, the extension of the bilateral agreement on the free movement of persons and flanking measures, the bilateral agreement on the taxation of savings, the bilateral agreement on Schengen/Dublin, the law on nuclear energy, the law on the infrastructure funds, the new law on foreigners, the reform of fiscal equalisation and tasks distribution, the new constitutional articles on education and the law on telecommunication. Data on these processes were gathered through approximately 250 semi-structured interviews with individual representatives of collective actors involved in the respective policy processes. Based on positional, decisional and reputational approaches (e.g. Knoke 1993, 30), 20-30 organisational actors per process were identified and interviewed. ${ }^{6}$ Besides the answers to the pre-structured questions, additional, qualitative pieces of information shared by the interview partners on a voluntary basis were collected in an interview protocol, which provided helpful information for the in-depth knowledge of cases. Further, the study of official documents provided supplementary information on the processes.

Methodologically, the study relies on an innovative combination (see Fischer 2011). First, Social Network Analysis (Wasserman and Faust 1994) tools are applied to reconstruct coalition structures in the 11 cases. Relying on such formal tools ensures that the same criteria are used for the reconstruction of the coalition structures across different types of actors and policy processes. Second, the 11 cases are compared with a QCA (e.g. Ragin 1987; Rihoux and Ragin 2009). QCA is a method for the systematic comparison of usually a medium (5-50) number of cases and relies on the systematic description of cases. It allows for complex causality, i.e. the fact that different combinations of causal conditions can lead to a particular outcome, and that the effect of a condition is dependent on its combination with other conditions. This method reduces the combination of conditions by eliminating redundant conditions and identifies necessary and sufficient conditions leading to an outcome. ${ }^{7}$

\footnotetext{
${ }^{5}$ The importance of the policy processes is based on a written expert survey among approximately 80 experts of Swiss politics conducted in 2007.

${ }^{6}$ Interviews were conducted between February and July 2008 by the author of this paper and four specifically trained colleagues.

${ }^{7}$ Sufficient conditions always lead to an outcome, but the outcome can also be caused by other, alternative conditions. Necessary conditions need to be present for an outcome to occur, but they do not automatically lead to the outcome (Ragin 1987).
} 
Nevertheless, I explicitly refrain from formulating strong hypotheses on necessity and sufficiency, as such causes are supposed to be rare in political decision-making. Fuzzy-set Qualitative Comparative Analysis (fsQCA), as used in this study, allows overcoming the inherent limitation of the dichotomisation of the conditions and the outcome. Fuzzy-set membership scores take on values between 0 and 1 (Ragin 2008; Rihoux and Ragin 2009).

\section{Calibration of outcome and conditions}

Actors in a coalition do not only have similar beliefs, but also need to coordinate their activities (Schlager 1995; Weible and Sabatier 2005; Henry 2011). Therefore, coalitions are identified with a two-step procedure. In the first step, actors are regrouped into blocks according to their profiles of convergence and divergence of beliefs. Based on a list comprising all actors participating in the process, interview partners were asked to select the actors with which their organisation had mainly convergent or divergent beliefs concerning the project. This results in a directed matrix with positive values indicating convergence and negative values indicating divergence of beliefs. These subjective perceptions of actors' agreement with other actors are a good proxy for their joint beliefs (Ingold 2011). Blocks are then identified with the "balance" procedure in Pajek (Batagelj and Mrvar 1996). This procedure continuously rearranges the matrix of actors until it reaches an arrangement that is closest to a pre-defined structure with only positive within-block ties and negative between-block ties (Nooy et al. 2005). Deviations from this ideal arrangement are indicated with an error term that varies according to the number of blocks (Doreian and Mrvar 2009). I selected the block structure with the lowest error term. Depending on the case, this procedure results in two to five blocks. Actors within one block have convergent beliefs, while actors from different blocks have divergent beliefs. However, as having the same beliefs is not enough for actors to form a coalition, the second step identifies actors within each block that cooperate at least indirectly. Based on a list comprising all actors participating in the process, interview partners were asked to select the actors with which their organisation was cooperating closely, i.e. had frequent contacts during the policy process. As cooperation always needs two actors, only reciprocated cooperation ties were used for the analysis. Based on the cooperation network among the actors within each block, I identified two cliques (Wasserman and Faust 1994) in UCINET (Borgatti et al. 2002). This allowed me to eliminate actors that have similar beliefs but are not well integrated in the cooperation structure within the block. ${ }^{8}$ An alternative criterion,

\footnotetext{
${ }^{8}$ Within each block identified before, the two clique with the highest internal cooperation density was selected.
} 
i.e. direct cooperation, is too strict, because a coalition might be composed of some important, leading actors and some less important actors. These do not need to cooperate directly as long as they all cooperate with the leading actors (Hojnacki 1998). Thus, actors sharing similar beliefs (step 1) and cooperating at least indirectly (step 2) form a coalition. Similar beliefs are analysed before cooperation, because it is the more important criterion for the identification of a coalition. I rely on a broad and neutral definition of cooperation, so that the fact that political actors cooperate closely does not necessarily mean that they agree on the substantive policy issue at stake. While internal cooperation is important for a coalition, cooperation also occurs across coalitions. The information on cooperation is therefore less adapted for the first step of the identification of coalitions.

The power of coalitions is calculated in a third step. This is done by aggregating the reputational power of each actor in the coalition. Actors' reputational power is based on information from the interviews. From the same list comprising all actors participating in the process, interview partners were asked to indicate those actors that, in their view, were very influential in the policy process. Based on these answers, a score of reputational power was calculated for each actor, corresponding to the average of the judgements for a given actor by all interview partners. The aggregation on the coalition level is then computed as the average between the "part-of-the-sum" and the average score of the reputation of each coalition. ${ }^{9}$ Table A.1 in the Appendix gives an overview of the calibration of the outcome. The transformation from the indicator for power of the most powerful coalition to fuzzy-values is based on the direct method of calibration for interval variables (Ragin 2008). The crossover point is defined at 50, i.e. if (in the presence of at least three coalitions) one coalition has $50 \%$ of power.

Tables A.2-A.4 in the Appendix present the calibration of the conditions. For the assessment of the degrees of Europeanisation and federalism, substantive case knowledge stemming from qualitative information from the interviews and documentary sources is used. Fully federalist cases are given by projects that aim at reforming the distribution of competences between the Confederation and cantons. The education reform, for example, revised the distribution of competences between the Confederation and the cantons in the domain of education and is therefore a fully federalist case

\footnotetext{
9 The "part-of-the-sum" measure (summing up the reputational power of actors in the coalition and expressing the sum as the part of the total power of all coalitions) tends to overestimate the power of coalitions that contain a lot of actors with little power. The average measure (calculating the average reputational power of all actors in a coalition) tends to underestimate the power of these coalitions. Using the mean of the two measures enables me to control for these potential biases.
} 
Table 1. Calibration of outcome and conditions

\begin{tabular}{lcccc}
\hline \hline Case & $\begin{array}{c}\text { Dominant coalition } \\
(\mathrm{DOM})\end{array}$ & $\begin{array}{c}\text { Federalism } \\
\text { (FED) }\end{array}$ & $\begin{array}{c}\text { Europeanisation } \\
\text { (EUR) }\end{array}$ & $\begin{array}{c}\text { Open venues } \\
\text { (OPEN) }\end{array}$ \\
\hline Nuclear & 0.26 & 0.2 & 0.2 & 0.33 \\
Pension & 0.08 & 0 & 0 & 0.28 \\
Fiscal equalisation & 0.70 & 1 & 0 & 0.77 \\
Budget & 0.82 & 0.2 & 0 & 0.62 \\
Persons & 0.83 & 0.2 & 0.6 & 0.35 \\
Savings & 0.85 & 0 & 0.8 & 0.17 \\
Schengen & 0.73 & 0.4 & 0.8 & 0.13 \\
Foreigners & 0.81 & 0.4 & 0.4 & 0.65 \\
Education & 0.91 & 1 & 0 & 0.81 \\
Telecom & 0.37 & 0 & 0.4 & 0.08 \\
Infrastructure & 0.62 & 0.6 & 0 & 0.56 \\
\hline \hline
\end{tabular}

(fuzzy-value 1). A case is considered fully Europeanised if it only includes a bilateral treaty with the EU. The agreement on Schengen/Dublin is a mostly Europeanised case, as the bilateral treaty was accompanied only by some minor domestic adaptations (0.8). The pension scheme reform, on the contrary, did not concern cantons at all, and the EU did not influence this process either. This case is therefore fully non-federalist and fully domestic (0). The openness of venues is assessed by two indicators: the percentage of venues in the preparatory phase constituting formal access points for non-state actors ${ }^{10}$ and the percentage of non-state actors participating in all venues in the preparatory phase. The second indicator is calculated as the average of each venue's openness. This again is expressed as the percentage of all non-state actors involved in the process that participated in the given venue. To assess their participation at the different venues in the preparatory phase of the policy process, interview partners were asked in which venues their organisation was involved from a list of all venues in the preparatory phase. The final indicator on the openness of the process is calculated as the average of both indicators. For the transformation into fuzzy-values, I rely on the direct method of calibration for interval variables (Ragin 2008). The crossover point is defined at 0.5 , which indicates that venues are neither open nor closed to non-state actors.

Table 1 shows the fuzzy-values for the outcome and the conditions. DOM represents the outcome of the analysis, i.e. the set of cases with a

\footnotetext{
10 The reconstruction of the venues of the policy process is based on documentary sources and was validated by the interview partners.
} 
Table 2. Truth table for the analysis of dominant coalitions

\begin{tabular}{lccccl}
\hline \hline FED & EUR & OPEN & Consistency & DOM & Strong members \\
\hline 0 & 1 & 0 & 0.99 & 1 & Persons, Schengen, Savings \\
1 & 0 & 1 & 0.98 & 1 & Fiscal equalisation, Education, Infrastructure \\
0 & 0 & 1 & 0.91 & 1 & Budget, Foreigners \\
0 & 0 & 0 & 0.67 & 0 & Telecom, Pension, Nuclear \\
\hline \hline
\end{tabular}

Note $:$ FED $=$ federalism; EUR $=$ Europeanisation; $\mathrm{OPEN}=$ open venues; $\mathrm{DOM}=$ dominant coalition.

dominant coalition. The conditions are abbreviated by FED (federalist cases), EUR (Europeanised cases) and OPEN (cases with open venues).

\section{Analysis}

\section{Sufficient conditions for the emergence of a dominant coalition ${ }^{11}$}

The combination of three conditions results in eight possible configurations. Table 2 shows the four combinations that are empirically observed. The remaining combinations are logical remainders and do not appear in the table. ${ }^{12}$ The cases listed in the last column of each row are its strong members, i.e. cases lying more inside than outside of the given set. The consistency scores indicate to what extent the empirical observations support the postulate that the combination of conditions in a row is sufficient for the emergence of the outcome. Rows of the truth table whose strong members are members of the outcome set (and simultaneously have a consistency value of at least 0.75 ) are coded with the value 1 ; the others are coded 0 (Schneider and Wagemann 2010). Compared with stricter criteria, this focus on strong members results in solutions with higher coverage but lower consistency values. In order to explain a maximum of cases, the highest possible coverage values should be reached. ${ }^{13}$ For the reduction of the solution term, I focus on the complex solution that makes no simplifying

11 Table A.5 in the Appendix presents the results for the analysis of necessary conditions. Results correspond to the analysis of sufficiency and theoretical expectations. Non-federalism, a domestic process and closed venues are all necessary conditions for the emergence of competing coalitions (based on a consistency value of at least 0.90; see Schneider and Wagemann 2010). No condition is necessary for the formation of a dominant coalition.

${ }^{12}$ Logical remainders are combinations of conditions that are not observed. For most of these, it is likely that they do exist in reality. Some combinations, like Europeanised cases with open venues, however, are most likely not observable in reality.

${ }^{13}$ Empirical applications indicate that coverage levels ranging from 0.60 to 0.70 are already relatively high (Schneider and Grofman 2006). 
Table 3. Sufficient conditions for the emergence of a dominant coalition

\begin{tabular}{lcccl}
\hline \hline & Consistency & $\begin{array}{c}\text { Raw } \\
\text { coverage }\end{array}$ & $\begin{array}{c}\text { Unique } \\
\text { coverage }\end{array}$ & Cases covered \\
\hline eur*OPEN + & 0.93 & 0.62 & 0.44 & $\begin{array}{c}\text { Fiscal equalisation, } \\
\text { Education, Budget, } \\
\text { Infrastructure, Foreigners }\end{array}$ \\
fed*EUR*open & 0.99 & 0.42 & 0.23 & $\begin{array}{c}\text { Persons, Schengen, Savings } \\
\text { Solution }\end{array}$ \\
$\begin{array}{l}\text { Total consistency } \\
\text { Total coverage }\end{array}$ & $\begin{array}{c}0.94 \\
\text { eur OPEN + fed*EUR*open }\end{array}$ & & \\
\hline \hline
\end{tabular}

Notes: Intermediate solution (assumptions FED, EUR, OPEN): EUR + OPEN.

Easy solution: EUR + OPEN.

OPEN $=$ open venues; EUR $=$ Europeanisation; FED $=$ federalism .

assumptions, i.e. no assumptions on the outcome of logical remainders (Ragin 2008). All analyses are conducted with the computer program fsQCA (Ragin et al. 2009).

Table 3 shows the solution term. The consistency and coverage scores express to what extent statements about set-theoretic relations between conditions and an outcome enjoy empirical support. ${ }^{14}$ Two types of policy processes, i.e. domestic processes with open venues and Europeanised, nonfederalist processes with closed venues, lead to dominant coalitions.

The first sufficient combination of conditions, i.e. a domestic process with open venues, lends support to Hypothesis 3, which states that open venues contribute to the emergence of a dominant coalition. However, the comparative analysis indicates that the effect of process openness on the coalition structure holds only for domestic processes. ${ }^{15}$ Open venues in the preparatory phase of the policy process give actors the opportunity to meet,

14 The consistency score provides information on the extent to which the empirical observation supports the postulate of a perfect relationship between the conditions and the outcome, or how well the solution formula describes the cases. The coverage measure is an indicator of the empirical importance of a relationship. It indicates what proportion of the fuzzy-membership values of the cases in the set of the outcome can be explained by the solution (Ragin 2008). In the tables, the asterisk stands for the logical "and" and the plus sign stands for the logical "or". Conditions and outcomes written with capital letters stand for their presence; those in lower case letters indicate the absence of the phenomenon.

${ }^{15}$ Given that both venue openness and a domestic process are required in order for a combination of conditions to be sufficient for the outcome to occur, the analysis does not allow for conclusions about the effect of venue openness in Europeanised processes. However, theory suggests that the existence of Europeanised processes with open venues is very unlikely anyhow, as the pace of international negotiations complicates the broad inclusion of non-state actors 
Table 4. Truth table for the analysis of competing coalitions

\begin{tabular}{lccccl}
\hline \hline FED & EUR & OPEN & Consistency & DOM & Strong members \\
\hline 0 & 0 & 0 & 0.83 & 1 & Telecom, Pension, Nuclear \\
0 & 0 & 1 & 0.64 & 0 & Budget, Foreigners \\
1 & 0 & 1 & 0.50 & 0 & Fiscal equalisation, Education, Infrastructure \\
0 & 1 & 0 & 0.47 & 0 & Savings, Persons, Schengen \\
\hline \hline
\end{tabular}

Note $:$ FED = federalism; EUR = Europeanisation; OPEN = open venues; $\mathrm{DOM}=$ dominant coalition.

exchange information and learn about their beliefs, and thereby reduces costs for coalition formation. A closer look at each case illustrates how actors took advantage of these opportunities. In the project on the law on foreigners, the dominant coalition, including the federal administration, public and business interest groups and centre-right and right-wing political parties, formed during the very open preparatory phase. Already the first report on the project in 1995 was subject to a consultation procedure, allowing actors to react and express their preferences. In addition, the governing parties met in a working group, and the representatives of the federal and cantonal agencies, as well as interest groups dealing with the problem, had the opportunity to form a dominant coalition in no fewer than three working groups and expert committees preparing the project. In the case of the fiscal equalisation scheme, open venues allowed for strong cooperation between the Confederation and the cantons in the project organisation and in several project groups. These bipartite bodies allowed a careful elaboration of a mutually acceptable solution (see also Braun 2009). The dominant coalition of centre-right parties, business associations and the federal government in the case of the programme of budget relief was also clearly favoured by open venues. On the one hand, centre-right parties pressured the government by means of parliamentary motions, ${ }^{16}$ and the parliamentary delegation on finance and the finance committees of both chambers were involved in the process very early. On the other hand, cantons were consulted in order to avoid increasing costs for them as a consequence of budget cuts at the level of the Confederation, and were thus included in the dominant coalition. In the case of the education reform, after

(e.g. Moravcsik 1994; Sciarini et al. 2002, 2004). Further, empirical evidence from my cases shows that venue openness is among the lowest in the Europeanised cases (see Table 1).

${ }^{16}$ Interviews: Christian-Democratic Party, St.Gallen, 21 April 2008; Federal Finance Administration, Berne, 20 March 2008 and Swiss People's Party, Mettmenstetten, 23 June 2008. 
an initial blockage by the cantons, they were included as equal partners in the preparation of the bill (see Fischer et al. 2010). In addition, because the parliamentary commissions played an unusually strong role and, together with the Conference of Cantonal Directors of Education, worked out a compromise in many joint meetings, political parties were strongly involved in extremely open venues. Finally, in the case of the infrastructure fund, the initiative of the administration to bring together all key actors of the domain of traffic and transport immediately after the rejection of the predecessor project was the basis for the emergence of a consensus within a dominant coalition. ${ }^{17}$ In addition, the political parties consulted via the parliamentary committees and cantons as important players in the domain of traffic and transport policy were included in the process via the Conference of Cantonal Directors of Public Transport and the Conference of Cantonal Directors of Building, Planning and Environment.

An alternative sufficient condition for the emergence of a dominant coalition is given by the combination of Europeanised, non-federalist processes with closed venues. This lends support to Hypothesis 2, which postulates that Europeanisation contributes to the emergence of a dominant coalition. However, according to empirical evidence from the comparative analysis, this is only the case in non-federalist processes with closed venues. ${ }^{18}$ In Europeanised processes, the executive has to defend the treaty it negotiated internationally on the domestic level. It therefore has to gather domestic support before or during the international negotiation phase. In the three cases of the bilateral treaties on the free movement of persons, the taxation of savings and Schengen/Dublin, a dominant coalition with actors from the centre and the left was opposed to a minority coalition of the nationalconservative and extreme right. In the case of the free movement of persons, the strong efforts of the federal government to create a dominant coalition at the domestic level are obvious. Already during the negotiation phase, a tripartite working group with representatives of the administration, trade unions and business associations was formed in order to address the strong demand from the left for an extension of the flanking measures for the protection of the domestic workforce. Without the support of the left and the almost certain rejection of the treaty by the national-conservative right,

17 Interviews: Cantonal Directors of Public Transport, Solothurn, 28 May 2008; Conference of Cantonal Directors of Building, Planning and Environment, Zurich, 28 April 2008 and SocialDemocratic Party, Schaffhausen, 23 June 2008.

${ }^{18}$ Results do not allow conclusions to be made about Europeanised processes that are also federalist and/or have open venues. However, as explained in FN15, Europeanised processes with open venues are rather unlikely. Given the Confederations' exclusive competence for the international relations of the country, the existence of processes that are both Europeanised and federalist is also very unlikely. 
the extension of the treaty would have been doomed to failure. ${ }^{19}$ Thanks to their concessions concerning the extension of the flanking measures, the government could win the support of the left and integrate it into the dominant coalition. Concerning the treaty on Schengen/Dublin, there was no comparable threat from the left. Still, the government informally negotiated with the cantons affected by the shifts of competences concerning the border guard and police forces. ${ }^{20}$ In addition, many other interests affected by the treaty (tourism, banking, gun possession, data protection) were involved via their federal agencies in the inclusive negotiation delegation. ${ }^{21}$ Finally, in the case of the agreement on the taxation of savings, Swiss banks as the main stakeholders were heavily involved in the elaboration of the Swiss proposal for negotiations. Given that the proposal elaborated in cooperation with the banks proved successful in the international negotiations, the federal government had provided the necessary domestic support for the agreement. ${ }^{22}$

Evidence from the cases lends strong support for the claim that both Europeanisation and open venues contribute to the emergence of a dominant coalition of actors. While the first brings constraints and urges state executives to form dominant coalitions, the second reduces the costs for actors' coordination and presents them with opportunities to form a dominant coalition. According to the results, the third condition included in the analysis, i.e. federalism, is not related to the emergence of a dominant coalition. I therefore must reject Hypothesis 1. Indeed, it could well occur that the Confederation and the cantons are unable to build a dominant coalition, or that not all cantons can be included. ${ }^{23}$

\section{Sufficient conditions for a structure of competing coalitions}

Table 4 presents the truth table for the analysis of competing coalitions. Table 5 shows the combination of conditions that are sufficient for the emergence of competing coalitions. Only a specific combination of conditions, i.e. non-federalist and domestic processes with closed venues, leads to a structure of competing coalitions. This finding lends further support to Hypotheses 2 and 3 (and some support to Hypothesis 1). If all three

19 Interview: State's Secretary for Economic Affairs, Basel, 6 March 2008.

${ }^{20}$ Interview: Radical-Democratic Party, Zurich, 21 April 2008.

${ }^{21}$ Interviews: Federal Police Administration, Berne, 30 June 2008; Swiss Association for Shooting Sports, Lucerne, 10 April 2008.

22 Interviews: Integration Office, Berne, 23 April 2008; Swiss Bankers' Association, Basel, 22 April 2008.

${ }^{23}$ However, all federalist projects in this analysis do also have open venues and all of them result in a dominant coalition. Thus, the formation of a dominant coalition in these federalist projects seems to happen according to the logic of open venues, which represents a more general explanation for the emergence of a dominant coalition. 
Table 5. Sufficient conditions for the emergence of competing coalitions

\begin{tabular}{lccc}
\hline \hline & Consistency & Raw coverage & Unique coverage \\
\hline fed"eur"open & 0.83 & 0.81 & 0.81 \\
\hline \hline
\end{tabular}

Notes: Intermediate solution (assumptions fed, eur, open): fed "eur*open.

Easy solution: eur*open.

$\mathrm{FED}=$ federalism; EUR $=$ Europeanisation; OPEN $=$ open venues.

conditions are needed for the explanation of competing coalitions, this suggests that every condition for itself can potentially explain the emergence of a dominant coalition.

In non-federalist and domestic projects, the government has no immediate institutional constraint - or incentive - to build a dominant coalition. As different domestic societal interests should be accommodated, there is not one partner with which to find a compromise, but at least two opposing sides. In addition, without the opportunity of consultation and negotiation in open venues, no dominant coalition can be formed.

Cases with competing coalitions include the pension scheme reform, the law on nuclear energy and the law on telecommunications. The pension scheme reform opposes the left and the right. On the one side, the left parties and trade unions, as representatives of women and workers, would have been the main and direct losers of the proposed revision. On the other side, the centre-right parties and business associations represent the employers that are partially responsible for financing the pension scheme. State actors were aware of this important conflict and tried to open up venues in the preparatory phase of the policy process. Social partners and the cantons did have some access to the interdepartmental working group. Accordingly, a certain degree of consensus, including an increase in the value-added tax instead of the contribution from wages, was found in the preparatory phase. ${ }^{24}$ However, it also became increasingly clear that there were large concerns on the left side, particularly regarding the flexibility of the retirement and reduction of the widow's pension. ${ }^{25}$ As opposed to trade unions, women's associations and left parties, i.e. actors particularly concerned by the reduction of the widow's pension, were not

${ }^{24}$ Interviews: Swiss Association of Employers, Zurich, 10 March 2008; Federal Office of Social Security, Fribourg, 28 February 2008/Christian-Democratic Party, Luzern, 29 April 2008.

${ }^{25}$ Interviews: Federal Office of Social Security, Fribourg, 28 February 2008; Swiss People's Party, Berne, 11 June 2008; Green Paty, Berne, 1 April 2009; Christian-Democratic Party, Luzern, 29 April 2008. 
intensely included in the venues of the policy process. ${ }^{26}$ The relevant discussions were therefore postponed to parliament, where the Federal Council's proposal was narrowly supported by a centre-right coalition. ${ }^{27}$ Finally, the left coalition challenged the bill in an optional referendum, where the project failed to pass.

Since the law on telecommunications is only indirectly Europeanised and thus not directly linked to an international agreement, the federal government was not constrained to form a dominant coalition to support an international treaty. Indeed, different coalitions of private actors formed. First, there was a coalition of centre parties, which, together with the alternative providers and regulatory authorities, aimed to liberalise the last mile. Second, the former monopolist Swisscom, obviously opposed to further liberalisation, formed a coalition together with left parties and trade unions that were worried about the impact of liberalisation on the "public service" and the labour market. Third, the Swiss People's Party played an ambivalent role during the process but finally opposed liberalisation. Owing to the high complexity of the domain and pressure from the regulatory authority and the Federal Court, the preparatory phase took place mainly at the administrative and judicial levels and remained closed to external actors. Political parties or interest groups were hardly involved in the preparation of the bill. The federal government could therefore not form a sufficiently dominant coalition. In the case of the nuclear energy law, the federal government and its administration tried to develop a compromise between the pro-nuclear centre-right coalition and the anti-nuclear left coalition. Without immediate constraints to form a dominant coalition, reaching a compromise in this traditionally conflictive policy domain proved difficult. Despite some officially open venues, non-state actors were unwilling or unable to actively participate in the preparations of the bill.

\section{Conclusions}

This paper studies the institutional conditions under which given coalition structures in policy processes emerge. By so doing, it tackles the interplay between beliefs, institutions and coalition formation. This aspect has been largely neglected in the literature on coalition formation in the policy process (Weible and Sabatier 2005; Sabatier and Weible 2007; Weible et al. 2011; Leifeld and Schneider 2012).

\footnotetext{
26 Trade unions, which were present in the preparatory phase, are - contrary to left parties not typical representatives of the new, value-based social demands like the one for gender equality (Häusermann et al. 2004, 50).

${ }^{27}$ Interview: Federal Office of Social Security, Berne, 14 February 2008.
} 
Institutions refer to the formal and informal norms that both constrain and enable the behaviour of political actors (Ostrom 1990, 2005; Lubell et al. 2012). This analysis took into account the institutional conditions of federalism, Europeanisation and venue openness. First, federalist projects present a constraint for coalition formation, as they define the actors whose agreement is absolutely needed, i.e. the cantons. In the federalist cases under study, cantons were included through open venues. This seems to be the more general explanation for the emergence of a dominant coalition than federalism. Second, Europeanisation constrains state actors to form a dominant coalition in order to secure domestic support for the international treaty. This is best illustrated by the project on the free movement of persons, where demands of the left were satisfied in order to include it in a dominant coalition. Third, open venues present an opportunity for actors to form a dominant coalition. The possibility to meet and negotiate in open venues reduces the costs of coalition formation for actors. For example, in the project of the infrastructure funds, the effort of the state administration to bring together all interested actors at the beginning of the policy process was the basis for the formation of a dominant coalition. On the contrary, without any of the three institutional conditions present, actors have a hard time forming a dominant coalition and tend to compete in different, equally strong coalitions.

Understanding coalitions is important because the coalition structure influences the possibility for policy change, at least indirectly. If a dominant coalition wants to change the policy in a policy subsystem, minority coalitions are most certainly unable to block change. For example, the agreement on Schengen/Dublin or the fiscal equalisation reform, both cases with a dominant coalition, represent important policy changes in their respective policy subsystems. On the contrary, with a structure of competing coalitions, policy change is hard to achieve. For example, the pension scheme reform was defeated in a popular vote, and a new project was abandoned in parliament a few years later. The telecommunications reform corresponds to a technically unsatisfying compromise solution, but not to the initially intended liberalisation of the domain.

The analysis shows that institutions influence coalition formation. However, one should take into account that this influence is not deterministic and that individual agency can further complicate things (Lubell et al. 2012; Radaelli et al. 2012). The institutional context simply defines the framework under which decision-making takes place, but does not guarantee that actors act accordingly. For example, open venues give actors an opportunity to negotiate, but it does not guarantee the successful formation of a dominant coalition. Similarly, state actors might not manage to include all the actors they need in their coalition in support of the international treaty. Further, it 
should be noted that at least state actors have the potential to partly influence the openness of decision-making venues. Actors might therefore also try to use institutional conditions in order to achieve their outcomes of interest.

The analysis in this paper is based on one of several possible strategies to reconstruct coalitions, as well as only 11 cases. While I tried to be as transparent as possible concerning the choices in the different steps of the reconstruction of coalitions, others might disagree about some elements of the procedure. However, it is unlikely that modifying one of the several steps for the reconstruction of coalitions fundamentally affects the fuzzy-set values for the cases, and thereby the results of the analysis. Further, while the 11 most important policy processes in Switzerland between 2001 and 2006 cover a large set of policy subsystems and can therefore be considered to represent the political system of Switzerland as a whole, one should still be careful in generalising the results from this analysis. First, results might not be valid for less important processes. For example, in less important processes, it might be easier to form a dominant coalition even with less open venues. Second, results might only be partly exportable to other countries. Opening up the venues of political decision-making might often allow compromise seeking, but the ability to do so is also dependent on the political culture of a country. Further, results including the condition of federalism are obviously not valid for non-federalist countries. Europeanisation is present in many countries, but its effects on coalition structures might depend on the specific system of government. However, coalition formation in other political systems is also influenced by different institutional conditions, and not by beliefs alone. Future research should take institutional variation across countries and policy subsystems into account.

\section{Acknowledgements}

The author would like to thank Sandrine Bossy, David Keller, Guenda Malinverni and Denise Traber who contributed to the data gathering. This article is part of a wider research project sponsored by the Swiss Science Foundation (Grant No. 100012-113964). Thanks for their helpful comments also go to Karin Ingold, Pascal Sciarini, Anke Tresch and to the editor and three anonymous reviewers of this journal.

\section{References}

Adam S. and Kriesi H. (2007) The Network Approach. In Sabatier P. A. (ed.), Theories of the Policy Process. Boulder, CO: Westview Press, 129-154.

Batagelj V. and Mrvar A. (1996) PAJEK - Program for Large Network Analysis, http://vlado. fmf.uni-lj.si/pub/networks/pajek/. 
Baumgartner F. R. and Jones B. D. (1991) Agenda Dynamics and Policy Subsystems. The Journal of Politics 53(4): 1044-1074.

— (1993) Agendas and Instability in American Politics. Chicago: The University of Chicago Press.

Borgatti S. P., Everett M. G. and Freeman L. C. (2002) UCINET for Windows: Software for Social Network Analysis. Harvard, MA: Analytic Technologies.

Börzel T. and Risse T. (2000) When Europe Hits Home: Europeanization and Domestic Changes. European Integration Online Papers 4(15): 1-23.

Braun D. (2009) Constitutional Change in Switzerland. Publius: The Journal of Federalism 39(2): 314-340.

Doreian P. and Mrvar A. (2009) Partitioning Signed Social Networks. Social Networks 31: $1-11$

Fischer M. (2011) Social Network Analysis and Qualitative Comparative Analysis: Their Mutual Benefit for the Explanation of Policy Network Structures. Methodological Innovations Online 6(2): 27-51.

_ (2012) Entscheidungsstrukturen in der Schweizer Politik zu Beginn des 21. Jahrhunderts. Zürich and Chur: Verlag Rüegger.

Fischer M. and Sciarini P. (2013) Europeanization and the Inclusive Strategies of Executive Actors. Journal of European Public Policy 20(10): 1482-1498.

Fischer M., Sciarini P. and Traber D. (2010) The Silent Reform of Swiss Federalism: The New Consitutional Articles on Education. Swiss Political Science Review 16(4): 747-771.

Häusermann S., Mach A. and Papadopoulos Y. (2004) From Corporatism to Partisan Politics: Social Policy Making Under Strain in Switzerland. Swiss Political Science Review 10(2): $33-59$.

Heaney M. (2006) Brokering Health Policy: Coalitions, Parties, and Interest Group Influence. Journal of Health Politics, Policy and Law 31(5): 887-944.

Henry A. D. (2011) Ideology, Power, and the Structure of Policy Networks. Policy Studies Journal 39(3): 361-383.

Hojnacki M. (1998) Organized Interests' Advocacy Behavior in Alliances. Political Research Quarterly 51(2): 437-459.

Hooghe L. and Marks G. (2003) Unraveling the Central State, But How? Types of Multilevel Governance. The American Political Science Review 97(2): 233-243.

Immergut E. M. (1990) Institutions, Veto Points and Policy Results: A Comparative Analysis of Health Care. Journal of Public Policy 10(4): 391-416.

Ingold K. (2011) Network Structures Within Policy Processes: Coalitions, Power, and Brokerage in Swiss Climate Policy. Policy Studies Journal 39(3): 435-459.

Knoke D. (1993) Networks of Elite Structure and Decision Making. Sociological Methods \& Research 22(1): 22-45.

(2011) Policy Networks. In Carrington P. and Scott J. (eds.), The SAGE Handbook of Social Network Analysis. London: SAGE Publications, 210-222.

Knoke D., Pappi F. U., Broadbent J. and Tsujinaka Y. (1996) Comparing Policy Networks Labor Politics in the U.S., Germany, and Japan. Cambridge: Cambridge University Press.

Kriesi H. (1995) The Political Opportunity Structure of New Social Movements: Its Impact on Their Mobilization. In Jenkins J. C. and Klandermans B. (eds.), The Politics of Social Protest. Minneapolis: University of Minnesota Press, 167-198.

Kriesi H. and Trechsel A. H. (2008) The Politics of Switzerland. Cambridge: Cambridge University Press. 
Kübler D. (2001) Understanding Policy Change With the Advocacy Coalition Framework: An Application to Swiss Drug Policy. Journal of European Public Policy 8(4): 623-641.

Laver M. and Schofield N. (1990) Multiparty Government: The Politics of Coalition in Europe. Oxford: Oxford University Press.

Leach W. D., Pelkey N. W. and Sabatier P. A. (2002) Stakeholder Partnerships as Collaborative Policymaking: Evaluation Criteria Applied to Watershed Management in California and Washington. Journal of Policy Analysis and Management 21(4): 645-670.

Leifeld P. and Schneider V. (2012) Information Exchange in Policy Networks. American Journal of Political Science 53(3): 731-744.

Linder W. (2005) Schweizerische Demokratie. Bern, Stuttgart and Wien: Haupt.

Lubell M., Scholz J., Berardo R. and Robins G. (2012) Testing Policy Theory With Statistical Models of Networks. The Policy Studies Journal 40(3): 351-374.

Mahoney C. (2007) Networking vs. Allying: The Decision of Interest Groups to Join Coalitions in the US and the EU. Journal of European Public Policy 14(3): 366-383.

Moravcsik A. (1993) Preferences and Power in the European Community: A Liberal Intergovernmentalist Approach. Journal of Common Market Studies 31: 473-523.

(1994) Why the European Community Strenghtens the State: Domestic Politics and International Cooperation. Working Paper No. 52 Cambridge: Harvard University Press.

Mueller W. C. and Strom K. (2000) Coalition Governments in Western Europe. Oxford: Oxford University Press.

Nohrstedt D. (2011) Shifting Resources and Venues Producing Policy Change in Contested Subsystems: A Case Study of Swedish Signals Intelligence Policy. Policy Studies Journal 39(3): 461-484.

Nooy W. D., Mrvar A. and Batagelj V. (2005) Exploratory Social Network Analysis with Pajek. New York: Cambridge University Press.

Ostrom E. (1990) Governing the Commons. The Evolution of Institutions for Collective Actors. Cambridge: Cambridge University Press.

- (2005) Understanding Institutional Diversity. Princeton: Princeton University Press.

Putnam R. D. (1988) Diplomacy and Domestic Politics: The Logic of Two Level Games. International Organization 42(3): 427-460.

Radaelli C. M., Dente B. and Dossi S. (2012) Recasting Institutionalism: Institutional Analysis and Public Policy. European Political Science 11: 537-550.

Ragin C. C. (1987) The Comparative Method. Moving Beyond Qualitative and Quantitative Strategies. Berkeley: University of California Press.

— (2008) Redesigning Social Inquiry: Fuzzy-Sets and Beyond. Chicago and London: University of Chicago Press.

Ragin C., Drass K. A. and Davey S. (2009) Fuzzy-Set/Qualitative Comparative Analysis 2.5. http://www.u.arizona.edu/ cragin/fsQCA/.

Rihoux B. and Ragin C. C. (2009) Configurational Comparative Methods: Qualitative Comparative Analysis (QCA) and Related Techniques. Thousand Oaks and London: SAGE Publications.

Sabatier P. A. (1987) Knowledge, Policy-Oriented Learning, and Policy Change: An Advocacy Coalition Framework. Science Communication 8: 649-692.

— (1998) The Advocacy Coalition Framework: Revisions and Relevance for Europe. Journal of European Public Policy 5(1): 98-130.

Sabatier P. A. and Weible C. M. (2007) The Advocacy Coalition Framework. In Sabatier P. A. (ed.), Theories of the Policy Process. Boulder, CO: Westview Press, 189-222. 
Scharpf F. W. (1988) The Joint-Decision Trap: Lessons from German Federalism and European Integration. Public Administration 66: 239-278.

(2006) The Joint-Decision Trap Revisited. Journal of Common Market Studies 44(4): 845-864.

Schlager E. C. (1995) Policy Making and Collective Action: Defining Coalitions Within the Advocacy Coalition Framework. Policy Sciences 28: 243-270.

Schneider C. Q. and Grofman B. (2006) It Might Look Like a Regression ... But It's Not! An Intuitive Approach to the Presentation of QCA and fs/QCA Results, COMPASSS Working Paper No. 39, http://www.compasss.org/wpseries.htm.

Schneider C. Q. and Wagemann C. (2010) Standards of Good Practice in Qualitative Comparative Analysis (QCA) and Fuzzy-Sets. Comparative Sociology 9: 397-418.

Schneider M., Scholz J., Lubell M., Mindruta D. and Edwardsen M. (2003) Building Consensual Institutions: Networks and the National Estuary Program. American Journal of Political Science 47(1): 143-158.

Sciarini P. (2006) Le processus législatif. In Klöti U., Knoepfel P., Kriesi H., Linder W., Papadopoulos Y. and Sciarini P. (eds.), Handbuch der Schweizer Politik. Zürich: Verlag NZZ, 491-525.

Sciarini P., Fischer A. and Nicolet S. (2004) How Europe Hits Home: Evidence from the Swiss Case. Journal of European Public Policy 11(3): 353-378.

Sciarini P., Nicolet S. and Fischer A. (2002) L'impact de l'internationalisation sur les processus de décision en Suisse: Une analyse quantitative des actes législatifs 1995-1999. Swiss Political Science Review 8(3/4): 1-34.

Thomas C. S. (2001) Political Parties and Interest Groups: Shaping Democratic Governance. Boulder and London: Lyenne Rienner.

Tsebelis G. (2002) Veto Players - How Political Institutions Work. New York and Princeton: Russell Sage Foundation and Princeton University Press.

Wasserman S. and Faust K. (1994) Social Network Analysis. Methods and Applications. Cambridge: Cambridge University Press.

Weible C. M. (2005) Beliefs and Perceived Influence in a Natural Resource Concflit: An Advocacy Coalition Approach to Policy Networks. Political Research Quarterly 58(3): 461-475.

Weible C. M. and Sabatier P. A. (2005) Comparing Policy Networks: Marine Protected Areas in California. The Policy Studies Journal 33(2): 181-201.

Weible C. M., Sabatier P. A., Jenkins-Smith H. C., Nohrstedt D., Henry A. D. and Deleon P. (2011) A Quarter Century of the Advocacy Coalition Framework: Introduction to the Special Issue. The Policy Studies Journal 39: 349-360. 


\section{Appendix}

Table A.1. Coalition structure and corresponding fuzzy-membership values

\begin{tabular}{|c|c|c|}
\hline Power distribution & Cases (power per coalition) & Fuzzy-value \\
\hline \multicolumn{2}{|c|}{$\begin{array}{l}\text { Dominant coalition: only one coalition or one coalition with about } 100 \% \\
\text { of power }\end{array}$} & 1.00 \\
\hline & Education $(89 / 11)$ & 0.91 \\
\hline & Savings $(79 / 21)$ & 0.85 \\
\hline & Persons $(77 / 21 / 2)$ & 0.83 \\
\hline & Budget $(75 / 16 / 8)$ & 0.82 \\
\hline & Foreigners $(74 / 26)$ & 0.81 \\
\hline & Schengen $(67 / 33)$ & 0.73 \\
\hline & Fiscal equalisation $(64 / 36)$ & 0.70 \\
\hline & Infrastructure $(58 / 15 / 14 / 12)$ & 0.62 \\
\hline \multicolumn{2}{|c|}{ Crossover point: one coalition with $50 \%$ of power (with at least three coalitions) } & 0.5 \\
\hline & Telecom $(47 / 31 / 22)$ & 0.37 \\
\hline & Nuclear $(44 / 28 / 27)$ & 0.26 \\
\hline & Pension $(36 / 33 / 31)$ & 0.08 \\
\hline \multicolumn{2}{|c|}{ Competing coalitions: two or more coalitions with the same amount of power } & 0 \\
\hline
\end{tabular}

Table A.2. Federalism and fuzzy-membership values

\begin{tabular}{|c|c|c|}
\hline Fuzzy-value & Criterion for calibration & Cases \\
\hline 1 & $\begin{array}{l}\text { Federalist: common project of Confederation and } \\
\text { cantons }\end{array}$ & $\begin{array}{l}\text { Fiscal equalisation, } \\
\text { Education }\end{array}$ \\
\hline 0.8 & Mainly federalist & \\
\hline 0.6 & Rather federalist, cantons strongly concerned & Infrastructure \\
\hline 0.5 & $\begin{array}{l}\text { Crossover point: half of the project concerns } \\
\text { the federalist competence distribution, } \\
\text { half of it only competences of the } \\
\text { Confederation }\end{array}$ & \\
\hline 0.4 & Mostly Confederation, cantons concerned & Schengen, Foreigners \\
\hline 0.2 & Mostly Confederation, cantons weakly concerned & Nuclear, Budget, Persons \\
\hline 0 & Non-federalist: only Confederation & Pension, Savings, Telecom \\
\hline
\end{tabular}




\section{Table A.3. Europeanisation and fuzzy-membership values}

\begin{tabular}{lll}
\hline \hline Fuzzy-value & Criterion for calibration & Cases \\
\hline 1 & Europeanised: only international treaty & \\
0.8 & International treaty with some domestic aspects & Savings, Schengen \\
0.6 & International treaty with important domestic aspects & Persons \\
0.5 & Crossover point: half of the project concerns an & \\
& $\quad$ international treaty, half of it a domestic project & \\
0.4 & Indirectly Europeanised project/domestic project with & Foreigners, Telecom \\
& strong international dependencies & Nuclear \\
0.2 & Mainly domestic project with some international & dependencies \\
0 & Domestic: only domestic project & Pensions, Fiscal equalisation, \\
& & Budget, Education, \\
& & Infrastructure \\
\hline \hline
\end{tabular}

Table A.4. Venue openness and fuzzy-membership values

\begin{tabular}{llc}
\hline \hline Openness of venues & Cases $(\varnothing$ openness) & Fuzzy-value \\
\hline Open venues & 0.75 & 1 \\
& Education $(0.65)$ & 0.81 \\
& Fiscal equalisation $(0.60)$ & 0.77 \\
& Foreigners $(0.55)$ & 0.65 \\
Crossover point: venues half open & Budget $(0.54)$ & 0.62 \\
& Infrastructure $(0.52)$ & 0.56 \\
& & 0.5 \\
& Persons $(0.45)$ & 0.35 \\
& Nuclear $(0.44)$ & 0.33 \\
Closed venues & Pensions $(0.42)$ & 0.28 \\
\hline \hline
\end{tabular}

Table A.5. Necessary conditions

\begin{tabular}{lccccc}
\hline \hline & \multicolumn{2}{c}{ Dominant coalition } & & \multicolumn{2}{c}{ Competing coalitions } \\
\cline { 2 - 3 } \cline { 5 - 6 } & Consistency & Coverage & & Consistency & Coverage \\
\hline Federalist project & 0.52 & n.r. & & 0.44 & n.r. \\
Non-federalist project & 0.68 & n.r. & & 0.90 & 0.52 \\
Europeanised project & 0.44 & n.r. & & 0.34 & n.r. \\
Domestic project & 0.74 & n.r. & & 0.98 & 0.50 \\
Open venues & 0.63 & n.r. & & 0.57 & n.r. \\
Closed venues & 0.65 & n.r. & & 0.92 & 0.59 \\
\hline \hline
\end{tabular}

Bold values indicate consistency scores of 0.9 or higher. 